Vol. 2 No. 1

Juni 2020

e- ISSN 2685 - 0559

p- ISSN 2684 - 673X

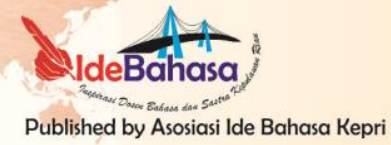

Jurnal

IdeBahasa

Impirasi Dosen Babasa dan Sartra

\title{
THE CONSTRUCTION OF POSTCOLONIAL DISCOURSE IN THE STORY ROBOHNYA SURAU KAMI \\ BY A. A. NAVIS
}

\author{
Resneri Daulay ${ }^{1}$ \\ Universitas Ahmad Dahlan (UAD), Yogyakarta, Indonesia \\ resneri.daulay@enlitera.uad.ac.id \\ Tomi Arianto ${ }^{2}$ \\ Universitas Putera Batam (UPB), Batam, Indonesia \\ tomi.arianto@puterabatam.ac.id
}

\begin{abstract}
The story of Robohnya Surau Kami by A. A. Navis is an indirectly provocative work of fiction which arouse eastern society, represented in the life of Minangkabau people at that time, to realize their helplessness in order to take the initiative and express their silenced voices. This short story directs people to carry out a reformist movement in their constraints to the traditions they have lived for centuries because of colonialism. This short story was made in the 1990s where many Minangkabau Ulemas tended to focus more on education and intellectual activity rather than physical resistance. Orientalist discourse manifests itself as an influential system of ideas or as a network of various intellectual interests and meanings that are implied in various contextual, social, political, and constitutional of colonial hegemony. As alluded above, surau becomes a symbol of the institutions used by the colonial to facilitate the process of inculcating ideology and religion as the means of control in society. The result of this research represented that the construction of postcolonial discourse in the story Robohnya Surau Kami by AA. Navis reflected into the concept of demonization, dehumanization, western hegemonic. Paradigms that places eastern culture as old-fashioned, backward and stupidity are a construction to build demonization in the story. Thus, through the character of Ajo Sidi as an agent, the eastern people represented by the grandfathers are alienated, instigated, and subsequently experience a divided identity called by dehumanization. This demonization and dehumanization continued to be created and maintained by instilling hegemonic doctrines even without violence.
\end{abstract}

Keywords: Orientalism, Post colonialism, Construction Discourse 
Vol. 2 No. 1

Juni 2020

e- ISSN 2685 - 0559

p- ISSN $2684-673 X$

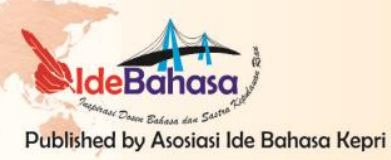

Jusmal

Ide Bahasa

Impirasi Dosen Balasa dan Sastra

\section{Introduction}

Postcolonial theory can be defined as a critical theory which attempts to express the consequences of colonialism. Postcolonial analysis can be used to explore hidden or deliberately hidden aspects, so that it understands how the power works. On the other hand, it dismantles the underlying disciplines, institutions, and ideologies. Postcolonial discourse is an inseparable relation between western and eastern power. Loomba (1998) described that postcolonialism did not come after colonialism and signify the disappearing of colonialism, but it became a continuity of colonialist traumatic domination and colonialist mental heredity. It works in line with a construction empowered with colonialist discursive dominance in terms of thought and mentality lasting in colonialized people.

The source of postcolonial theory was marked by the publication of Said (1978), Orientalism. The main thesis of Said's book uses the approach of the relationship between power and knowledge. Foucault (2007) defined orientalists as a problem of western scientific studies on Eastern which was not only solely driven by the interests of knowledge, but also the interests of colonialism. The purpose for understanding orientalists is to maintain its power, that is filled with ideological political visions and missions. The study is merely a form or continuation of colonialism. Eastern nation is constructed as a nation that is synonymous with irrationality, depravity, immorality, immaturity, and "different" from rationality, wisdom, maturity, and "normal" western.

Said's point of view (1978) seemed to express explicitly what was hidden in the consciousness of many people, especially those in the former Western colony now called the "third world", to rise, struggle, and find an awareness by demanding justice and equality. A lawsuit that emphasizes freedom and rejection of all hybrid blend of thought or power, for example, finds its most formulated form of philosophical thought as stated by Jacques Derrida and Michael Foucault. It is no coincidence that Gayatri C. Spivak, a famous figure for his great contribution in building postcolonial studies on an ongoing basis, wrote a lengthy introduction to Derrida (1982) book. In the introduction of the book, basically Spivak rejected all constraining and limiting powers, while at the same time, expressed his priority over freedom. The oppressed, colonized, and subaltern people must speak and take the initiative or action on their silenced voices.

The Story of Robohnya Surau Kami by A.A. Navis told about two different ways of thinking betweeen the character of grandfather and Ajo Sidi. This story centres on the setting of the Surau as the eastern representation. Surau referred to a symbol of institution and Minangkabau as the land of birth that shows a dimension of statehood directed to the life of indigenous or Eastern society. The diction of surau, and names of characters in the short story clearly describe the geographical dimension of 
Minangkabau society that is closely related to customs and cultures they have followed for years. In Surau, Minangkabau people studied about the way to understanding the universe and the hereafter; from learning about Tarekat, religious knowledge, selfdefence, as well as how to behave as godly people. Ajo Sidi is a missionary who has a mission to influence the grandfather (Gharim) to leave his habits. Through his gibberish, Ajo Sidi influenced grandfather that his actions were nothing but emptiness.

The representation of colonialism in the story describes how Ajo Sidi's role as an ideological agent and grandfather represented eastern culture. The postcolonial discourse in the story can be seen from how the western ideology through postcolonial agents and eastern cultures that have binary opposition and intertwined. This analysis can be traced using the postcolonial approach. Edward Said in his concept of demonization, dehumanization, western hegemonic. Paradigms that places eastern culture as old-fashioned, backward and stupidity are a construction to build demonization in the story. Thus, through the character of Ajo Sidi as an agent, the eastern people represented by the grandfathers are alienated, instigated, and subsequently experience a divided identity called by dehumanization. This demonization and dehumanization continued to be created and maintained by instilling hegemonic doctrines even without violence.

\section{Literature Review}

\subsection{Post Colonialism}

According to Ashcroft et al. (2002) the meaning and the scope of 'postcolonialism/post-colonialism' was now broadened, including the study and analysis of European territorial conquests, the various events of European colonialisms, the operations of an empire, the subject construction in colonial discourse, the resistance of those subjects, and most importantly perhaps the difference of responses between them and their contemporary colonial legacies in both pre-and postindependence countries. While its use has tended to focus on the cultural production, it is becoming widely used in historical, political, sociological and economic analyses, as these factors continue to engage with the impact of European imperialism upon the society of the world.

\subsection{Orientalism}

The study of white race and nonwhite race is discussed in Edward Said's book entitled Orientalism. Said (1978) said that becoming white people was a strong identity and it strengthened themselves. To have a white skin does not only mean to show the skin colour, but it also shows someone's identity. The identity of coloured skin only becomes the object that needs to be shunned and fought by white people if necessary. Said (1978) stated that white people are not only a reality but also a concept. To be white is a concrete and simple way to show the existence in this world, a way to hold on the reality, language, and thought. The writer simply conceptualizes 
orientalism in Said's theory related to an image creation. Moreover, Mashlihatin (2013) added that Western and Eastern building constructions do not only occur in both nationalities. It is undeniable that inherent mentality from the white people contributes to a strong relation between western and eastern because of the discourse of colonialism image creation. In the concept of the image creation, the writer divides it into theoretical understandings including demonization, dehumanization, and western hegemony.

\subsubsection{Demonization}

In postcolonial theory, the differences between western and eastern are the topics mostly discussed. Besides, other difference also exists as a function to degrade one element against each other such as old and new, traditional and modern, men and women, high and low culture, and various cultural phenomena which occupy positions as "men and women".

\subsubsection{Dehumanization}

Said (1978) stated that eastern nations are often seen as a structure built based on biological determinism and political moral teaching. Moreover, if there are unpleasant eastern elements (such as criminals, psychotics, women, and poor people) which have a different identity from virtuous western elements, the eastern is sometimes depicted as strange. The eastern nations are regarded as problems that need to be solved or limited because colonial powers straightforwardly want the East to be taken over.

\subsubsection{Western Hegemony}

Said adopted hegemony theory dominated by authoritative practice. This authoritarianism puts ideology as something that needs to be understood as an idea which supports the power of certain social party. Otherwise, in Foucauldian, Said (1978) adopted an idea that knowledge is functioned as colonialist tool to defend the power, fulfilled with ideological political interest, and the principle of understanding about a history which moves backward to return to the present in order to maintain a continuity.

According to Gramsci in Gupta (2003), hegemony happened when the oppressed party's intellection, especially the proletariat, obsessed and accepted the way of thinking from dominant party. The transformation and the takeover of intellection in hegemony theory is not only limited to a political field, but also a discourse with a strength from its physical. Postcolonial western hegemony is not done physically, but through the power of a discourse, like western and nonwestern, western and indigenous people, developed and developing countries, industrial and agricultural countries. The hegemony through a discourse is performed far effectively because it can be done over long distance without creating any direct intervention (Ratna 2010: 181-182).

\subsection{Previous Study}

There are many studies discussing the application of a postcolonial approach in literature. This study is one of other dimensions that sees how 
contestation of postcolonial discourse works in eastern society, especially in the story of Robohnya Surau Kami by A.A. Navis. From various existing studies, the writer summarizes several studies that have contributed to the development of idea for this study. These studies include:

The first journal was indexed in scopus by Lang (2009) which examined postcolonial discourse in the novel Small Island by Andrea Levy. The article discussed the deviation of postcolonial discourse in a way a text is read. According to Lang, the novel was made along with the commemoration of the $200^{\text {th }}$ of the slave trade and the enactment of slavery laws. From the result of this postcolonial schematic reading, Lang depicted the discrimination and struggle for a slavery abolition on an island also certain ethnic minority in a postcolonial perspective.

The second journal concentrated more on a criticism and concept of understanding in orientalism written by Khalil (2004). Khalil explored Said's argument in term of orientalism especially the issues related to epistemological understanding about the west and the east. In his opinion, none of these responses are comprehensive. Lewis counterargument ignored the philosophical issue as a base to bet, while Gandhi's response provided more promising alternative for a future knowledge about "the Eastern".

The other journal written by Waworuntu and Arianto (2019) used Bhabha's approach (1994) regarding a figure of identity experiencing a mimicry. In the journal, Waworuntu explained that an identity on mimicry produced hybridity, which is represented by Ali, and ambivalence through the character of the father. Both are immigrants who were influenced by a postcolonial thought. Arianto (2019) also explained the phenomenon of a postcolonial society in a collection of short stories entitled Jhumpa Lahiri. The article analyzes the existence of women in postindependence era who were psychologically under the reflection of postcolonial discourse. In another article, Arianto (2018) analyzed subaltern women through Eka Kurniawan's story which states that they were not able to speak and legitimized to be oppressed. The story of Sepasang Mata Dinaya Yang Teraniyaya reflects how symbolic violence in Bourdieu's concept (1986) is controverted by a country, a society, even smallest range of family to discredit women.

\section{Research Method}

Ratna (2004) said that data collection methods and techniques are basically a set of methods or techniques that became an extension of the human senses because the aim is to collect empirical facts related to research problems. The method used in this study was qualitative descriptive. The method can be interpreted as a work to understand the object that is the target of the study. The writer collected data by colecting data related to postcolonial discourse in the work itself. These data were divided into two parts, namely primary data and 
secondary data. The primary data of this study was in the story Robohnya Surau Kami. While secondary data was a collection of data outside the story, such as books, journals, essays and others related to the object of research.

Data analysis methods are basically ways to sort out, classify qualitative data so that later certain relations could be established between one data category and another. The analysis method that would be used in this research was the reading method. In this case, the text would be read in story Robohnya Surau Kami to establish communication with it. This communication would run continuously and back and fourth between the text and the reader, considering the text itself only exists whe the reader reads and literayure could only produce a response whe it is read.

\section{Result and Discussion}

The short story from A.A. Navis is begun with a depiction of spatial structure in a form of surau which refers to a symbol of institution and Minangkabau as the land of birth that shows a dimension of statehood directed to the life of indigenous or Eastern society. The diction of surau, and names of characters in the short story clearly describe the geographical dimension of Minangkabau society that is closely related to customs and cultures they have followed for years.

Talking about social life and community in Minangkabau, Social construction formed in religious perception of society which is inseparable from its habit is seen.
There is a well-known philosophy from Minangkabau stating that Adat Basandi Syara', Syara' Basandi Kitabullah (ABS $S B K)$, Syara' mangato, Adat mamakai. This philosophy seems to strengthen the existence of Islam in social life, and it is inseparable from Minang's daily life.

Surau is not only believed by Minangkabau people as a building for religious activity, but also as a place to learn about Minangkabau traditional advice, martial arts, randai, and other cultural traditions. Surau is also a place where people are preparing themselves to be mature in the future. However, there is still a value shifting found in the society caused by a constructed mentality, as the result of colonialism that has lasted for centuries.

Orientalist discourse is manifested as an influential system of idea, various concerns, and intertextual meaning which are applied into various contexts, society, politics, and constitution from colonial hegemony. As stated before, surau becomes a symbol of institution used by colonial to ease the process of theorizing an ideology and religion as a controlling tool in society. Meanwhile, Minangkabau is depicted as a representation of the eastern society who owns natural wealth, strong culture, and social norms. They are used by the colonial to maintain their dominance.

Berger \& Luckmann (1966) defined social control as one of the ways to control the dissidents. Besides, Joseph $S$ Rourcek, as stated in Soerjono Soekanto (1982), said that social control is either a planned or unplanned process which tends to 
educate. It also persuaded people to obey the valid social principle. Generally, it can be concluded that social control is a way or process of supervision, either planned or not, to invite, educate, and force people to behave under social norms. In the short story, religion and religious norms become a social tool in a society.

The writer divided the concept of image creation found in the story Robohnya Surau Kami into three aspects. They were:

\section{1) Demonization in creating traditional and modern image}

From a narrative structure of the story, the narrator's position, which refers to "I", is involved in the story. Although its position is not fully involved, it still makes the narrator know everything well because he positions himself using approaches to other characters. In this case, the narrator tells a story about a character of a garin surau, called as the grandfather, and Ajo Sidi, as a braggart who influences the grandfather.

The grandfather who acts as garin surau is represented as an eastern/indigenous person who experiences an ambivalence going through hybridity. The figure of grandfather is in opposition to Ajo Sidi, represented as an indigenous person, who criticizes the colonial boundaries that has been strongly merged with some parts of the Eastern to maintain the dominance.

A colonial exploitation comes along with a certain discourse which is related to the colonized people. A developing discourse tends to discredit colonized nation as weak, irrational, primitive and so on. The spread of this idea arouses certain consequences for "the Eastern" as colonized country which there is unbalanced relation between the colonizer and the colonized. The relation leaves social and cultural issues to society until now. Therefore, the constructed mentalities exist in ex-colonized country, and It can be seen from the grandfather's habitual activities. He forgets his past and focuses on his afterlife as seen from quotation:

"I have been here since I was young, haven't I? I did not remember that I had wife, child, family, like other people. I do not think about my own life. I do not seek for wealth or want to build a house. All my life, physically and spiritually, is given to Allah Subhanahu wataaala. I never trouble anyone else. Even I feel unwilling to kill a fly........" (Navis, 1955)

From the quotation above, a colonial discourse towards the Eastern shapes a helpless mentality of the grandfather. In other quotation, it is also illustrated from the action of Ajo Sidi, who tells a story about Haji Saleh which satirizes the grandfather's life.

"What do you always do in life?"

"I worship you, my God"

"Anything else?"

"My Lord, nothing do I do except worshipping You, exclaiming Your name, even in Your love, when I am sick, Your name is the one I always talk about......." (Navis, 1955)

The quotation highlights the illustration of Haji Saleh created by Ajo Sidi which 
satirizes the grandfather who has mentality as a part of colonized society.

This kind of mentality is preached intentionally by colonizer to maintain their dominance against the colonized. Said mentioned this as Orientalism, which involved the self-image of white people portraying their dreams and image to other party, the Orient. Furthermore, the Orient is considered as a reflection of Occident, the western. The western depicts their confusion to the eastern through colonization by depleting the natural resource, performing epistemic violence, "educating" the Eastern, and even colonizing the culture. This mentality ignores the richness and diversity of the eastern history. Furthermore, Orientalism is not only related to the representation or depiction of other people (sang Liyan - colonized community) but also to the mindset knowledge, and action based on certain point of view.

Spivak, in this case, explained that in the state of being oppressed and colonized, the subaltern needed to speak up, take an initiation, and perform an action regarding their silenced voice. It is portrayed from the action performed by Ajo Sidi. His habit, as a braggart, does not only mock other people, in fact, it also initiates others to raise the awareness about local people mentality which has been colonized for a long time. His illustration about Haji Saleh does not only refer to the grandfather but also to all societies in general to fight against the discourse construction of a colonial dominance.

After the death of the grandfather, Ajo Sidi does not stop his massive movement. Ajo Sidi really understands that his struggle to arouse community awareness regarding the mentality formed by former Dutch colony lasts forever. This is stated in quotation:

"I looked for Aji Sidi at his house. Yet I only met his wife.

And I asked her.

"He has gone. Ajo Sidi's wife answered"

"Did he not know the grandfather was passed away?"

"He did, He asked me to buy sevenlayer shroud for grandfather"

"And my question is.... ...... "Where did he go?"

"Working"

"Working, I repeated once again in emptiness.

"Yes, He went working." (Navis, 1955)

It represents A.A. Navis's struggle to create provocative work to make the society aware that they need to free themselves from a postcolonial doctrine. If the mindset still exists, the struggle will not be stopped.

\section{2) Dehumanization}

A mindset of discrediting the Eastern in the Western perspective leads us to dehumanization. Said (2010: 318) said that along with dehumanization, the Eastern was considered as a framework formed by biological determinism and political moral doctrine. Besides, if the unpleasant elements of the Eastern (such as criminals, madmen, women, and the poor) have a different identity from the virtuous elements of the Western, they are considered as strange. 
In the short story of Robohnya Surau Kami, dehumanization to the eastern is not directly done by the western, but by their own mindset which is influenced by the western thought. In the short story, it dichotomized into two-dimensional spaces, way of thinking, and culture. The two-dimensional spaces, in opposition binary, group an urban area and rural area along with shaped culture and way of thinking. These two representatives are reflected in the character of Ajo Sidi, a braggart, and the grandfather, a gharim masjid. The two-dimensional spaces form two gaps between the western and eastern mindset which affect the process of dehumanization in postcolonial construction.

The first construction of dehumanization is seen through the choice of regional topography between traditional market and village. The required regional topography gives an emphasis on the grandfather's dwelling place and the image of village community. It can be seen from the quotation:

"If years ago, Mister came to my birthplace by bus, Mister would get off near the market. Around 1 kilometre from the market, Mister would find a way to my village. On the narrow junction to the right, the fifth junction, turn to the alley. At the end of the street, Mister would find an old Surau. In front of the Surau, there was a pool which its water flowed through 4 shower taps." (Navis, 1955)

The setting of the story represents two-dimensional spaces reflected by
Ajo Sidi, classified as a civilized citizen because he comes from downtown, and the character of "l" who is returning to his hometown. Meanwhile, the village is portrayed as a remote, traditional village which is far away from a market, considered as a modern hub, and has many alleys. The construction of space builds a contrast dimension of binary opposition to emphasize the topography of the grandfather and people as plebeian, backward, and left behind. The setting of surau also represents a Muslim civilized place, adapted by Indonesian, which also reflect the Eastern. The relation between the setting of place and region topography implies the dehumanization link between western and eastern civilization in term of space.

The second construction of dehumanization is seen from the way the character of grandfather is discredited along with the nonsensical story told by Ajo Sidi. The grandfather, the representative of the Eastern, is considered as conservative character by Ajo Sidi. The reason is because the grandfather is described as someone who only thinks about himself, is ignorant, and close-minded. The characteristic is seen from the quotation:

"I was here since I was young, wasn't I? I did not remember that I had wife, child, family, like other people. I do not think about my own life. I do not seek for wealth or want to build a house. 
I never trouble anyone else. Even I am unwilling to kill a fly. But now, I am judged as cursed man. The bait of hell. Don't you think my God will be angry with me if that was what I did? Will I be cursed if I serve Him with all my life? I never think about my future, because I believe that God exists and loves his virtuous people" (Navis, 1995)

The grandfather is depicted as antisocial, and ignorant. He does not care about worldly life, yet he only busies with praying and worshipping God. Those characteristics are considered as big mistakes by Ajo Sidi. His profesion as gharim, whose daily activities are praying and worshipping God, is influenced by Ajo Sidi's nonsensical talk. Ajo Sidi considers the grandfather's actions as the eastern behaviour which causes his nation to be colonized. Ajo Sidi also influences the grandfather by giving him a story of an afterlife illustrated by the character of Haji Saleh. Haji Saleh does not enter the heaven, instead, he is thrown into the hell due to his mistake which always worshipping God without thinking about worldly life, according to Ajo Sidi's story.

The story indirectly constructs two dimensions of thinking which are Ajo Sidi, who has western thought, and the grandfather, who has spiritual soul and eastern thought. Ajo Sidi considers a worldly life is not only about God but also principles of capitalist thought. It is seen from his way of thinking on how to maintain social relationship, what the forest, sea and earth have which are stolen by other people as a loss. Therefore, the grandfather's worship activities for years are considered as empty and unvalued by Ajo Sidi. The grandfather feels unpleasant and worthless after hearing the story from Ajo Sidi. That is how the construction of postcolonial discourse works through dehumanization. All the superiorities and civilizations are parts of the western, while inferiorities and primitiveness are parts of the eastern.

\section{3) Western Hegemony}

The construction of postcolonial discourse process is supported by a hegemony which is done slowly or without any physical hardness. The story of Robohnya Surau Kami represents an epic story on how metaphorical language works to show how a hegemonic contestation is done to the eastern, through the character of the grandfather, by hybrid character such as Ajo Sidi. According to Said, who adapted Gramsci perspective, a hegemony happened when oppressed party's mindset, especially the proletarian, was obsessed and accepted the dominance's way of thinking. Transformation and takeover of the mindset are not only limited in politics, but also intellect, morality, religion, and taste. Because of the hegemony and Ajo Sidi's words, Ajo Sidi's nonsensical story affects to grandfather's action. This can be seen from the end of the story as described:

"So, it was the Ajo Sidi's story I heard from from grandfather. It was a story that saddened grandfather. The next day, when I wanted to go in early morning, my 
wife asked me if it was fine for me not to visit him.

"Who died?" I shockingly asked

"Grandfather"

"Grandfather?"

"Yes. He died horribly in surau at dawn. He cut his throat with a razor." (Navis, 1955)

The above quotation shows how Ajo Sidi takes a decision. He was eventually affected by Ajo Sidi's nonsensical story and committed suicide. Ajo Sidi, in this case, successfully kills him slowly with his nonsense. He justifies that the grandfather's action is totally a mistake. Ajo Sidi also omits the eastern elements, such as piety and devotion to God, through propaganda about worldly life. At the end of the story, Ajo Sidi only asked to buy sevenlayer shroud for the grandfather without feeling guilty. Moreover, he continues his job to spread the propaganda to other eastern people.

Transformation and takeover of the mindset were classified as a western hegemony. As it was discussed before when demonization and dehumanization were done, a strong perspective of someone who does ideological propaganda was applied by a hegemony which was done effortlessly and orderly. The western always kept constructing the eastern way of thinking to leave their originality and follow the western cultures. The western cultures were classified as full of capitalism, liberalism, and dichotomy which divided superiority and inferiority in terms of mentality and psychology. With the continuous process of hegemony, the western successfully omited a certain nation eastern culture only by doing a propaganda. It had the same case depicted by characters of the grandfather and Ajo Sidi. All the grandfather's deeds were gone because of Ajo Sidi's nonsense.

\section{Conclusion}

The story of Robohnya Surau Kami by A.A. Navis implicitly reflected how a contestation of postcolonial discourse happens. By using Erward Said's theory though a concept of orientalism, a postcolonial discourse was shown in the demonization of an image creation, dehumanization, and western hegemony. The image creation had an important role to create binary opposition between western and eastern through certain phenomena related to doctrinized and accepted idea about superiority and inferiority. Dehumanization is a form of execution to discredit the eastern through the its ideology. The image of inferiority which is taught into postcolonial mentality is strengthened with a discredit that the eastern is certainly primitive. As a result, there was nothing wrong if the eastern become backward and uncivilized. Moreover, the western hegemony continued to spread to change the mindset and the culture of the eastern. What Ajo Sidi and the grandfather experience in the short story described a postcolonial contestation which was depicted when Ajo Siji, with his nonsensical story, changed the grandfather's habits and even lead him to death. Ajo Sidi is considered as a postcolonial agent who spreads propaganda to make people 
leave their eastern culture and have hybrid identity.

\section{References}

Arianto, T. (2018). Symbolic violence against women in Sepasang Mata Dinaya Yang Terpenjara short story by Ni Komang Ariani. Kredo, 2(1), 53-64. https://doi.org/https://doi.org/10. 24176/kredo.v2i1.2526

Arianto, T., \& Ambalegin. (2019). Indoctrination against women in The Lowland by Jhumpa Lahiri. Okara: Jurnal Bahasa Dan Sastra, 12(2), 153-166. https://doi.org/http://dx.doi.org/1 0.19105/ojbs.v12i2.1935.

Ashcroft, B., Griffiths, G., \& Tiffin, H. (2002). Post-colonial studies: The key concepts. Choice Reviews Online, 39(06), 39-3153-39-3153. https://doi.org/10.5860/choice.39 $-3153$

Berger, P. L., \& Luckmann, T. (1966). The social construction of reality, the treatise in the sociology of reality. Doubleday.

Bhabha, H. K. (1994). The location of culture. Routledge.

Bourdieu, P. (1986). The forms of capital ( R. Nice, Trans.). In J.G. Richardson (Ed.), Handbook for theory and research for the sociology of education. Greenwood Press.

Derrida, J. (1982). Of grammatology. The John Hopkins University Press.

Foucault, M. (2007). Arkeologi Ilmu- ilmu kemanusiaan (B. Priambodo \& P. Boy, Trans.). Pustaka Belajar.

Gupta, A. F. (2003). The Language of postcolonial literatures. Language and Literature, 12(2), 188-190. https://doi.org/https://doi.org/10. 1177/096394700301200210

Khalil, A. (2004). Beyond a western self and non-western other: Edward Said and his critics on truth and representation. Studies in Religion/Sciences Religieuses, 33(3-4), 319-337. https://doi.org/https://doi.org/10. 1177/000842980403300303

Lang, A. (2009). Reading race in small island: Discourse deviation, schemata and the textual encounter. Language and Literature, 18(3), 316-330. https://doi.org/https://doi.org/10. 1177/0963947009105856

Loomba,

A. (1998). Colonialism/Postcolonialism.

Routledge Tylor and Francis Group.

Mashlihatin, A. (2013). Teori pascakolonialisme Homi $K$. Bhabha: Ontologi dan Epistemologinya. 2. https://poskolonialisme.wordpress .com/2013/02/02/teori-

pascakolonialisme-homi-k-bhabhaontologi-danepistemologinya/\#_ftn2

Navis, A.A. (1995). Robohnya Surau Kami.

https://www.academia.edu/18010 318/Cerpen_Robohnya_Surau_Ka mi_karya_AA_Navis 
Vol. 2 No. 1

Juni 2020

e- ISSN 2685 - 0559

Ratna, N. K. (2004). Teori, metode, dan teknik penulisan sastra. Pustaka Pelajar.

Said, E. (1978). Orientalism. Pantheon.

Soekanto, S. (1982). Sosiologi: Suatu pengantar. PT Raja Grafindo Persada.

Waworuntu, M. I. G. R., \& Arianto, T. (2019). Hibridity of the chacracters in My Son the Fanatic Story by Hanief Kureshi. Basis, 6(2), 197208.

https://doi.org/https://doi.org/10.

33884/basisupb.v6i2.1432 
Vol. 2 No. 1

Juni 2020

e- ISSN 2685 - 0559 